\title{
Effect of drought stress on morphophysiological traits in some traditional rice cultivars of Kokrajhar district, Assam, India.
}

Bhaskar Sarma ${ }^{1 *}$, Neeva Rani Basumatary ${ }^{1}$, Shamsun Nahar ${ }^{2}$, Bhaben Tanti ${ }^{2}$

${ }^{1}$ Genetics and Plant Breeding Laboratory, Department of Botany, Bodoland University, Kokrajhar, Assam, India. ${ }^{2}$ Genetics and Plant Breeding Laboratory, Department of Botany, Gauhati University, Guwahati, Assam, India.

Received: July 26, 2016; Revised: August 13; Accepted: August 25, 2016.

\begin{abstract}
Water status is one of the critical factors affecting rice production. Rice cultivars tolerant to drought stress at the vegetative stage were selected. Six traditional rice cultivars of Kokrajhar district, Assam, namely, Sali, Bora, Abu, Malsira, and two varieties of Joha (aromatic rice) viq., white and black Joha were included in this study. The germination index, plant growth, root architecture, leaf rolling, leaf death and leaf relative water content in plants subjected to drought stress for $0,7,14$ and 21 days were recorded. Based upon the levels of water stress tolerance, three groups of rice cultivars were recognized as highly drought-tolerant, moderately drought-tolerant and drought-sensitive cultivars. The Joha (white) rice cultivar was considered to be a highly drought-tolerant cultivar. The moderately drought-tolerant cultivars included Joha (black), Abu, Sali and Bora, whereas the Malsira cultivar was found to be sensitive to drought.
\end{abstract}

Key words: Rice; germination index; root architecture; leaf rolling; leaf death; leaf relative water content

\section{Introduction}

Rice is a kind of cereal grain which is most widely consumed as staple food, for large part of the world's human population especially in Asian countries. It is a kind of corn obtained from paddy; also known as the seed of the grass species (Oryza sativa). Rice supporting more than three billion people and comprising $50 \%$ to $80 \%$ of their daily calorie intake (Khush, 2005). A quarter of global rice production relies on rainfall rather than irrigation, so is vulnerable to the increased frequency of droughts and flooding predicted under climate change.

Water is an important factor in agricultural and food production yet it is a highly limited resource (Wang et al, 2012). Drought stress causes extensive loss to agricultural production worldwide, thus being a severe threat to sustainable agriculture. Feeding continuously increasing population with depleting water supply requires crop varieties that are highly adapted to dry environments (Foley et al, 2011). The frequent occurrence of abiotic stress such as drought has been identified as the major to the low productivity of rain fed environment. It is one of the commonest stresses which are experienced by the plants. Drought is a meteorological term and is commonly defined as the inadequacy of water availability including period without significant rainfall that affects the crop growth (Hanson et al., 1995) and soil moisture storage capacity and it occurs when the available water in the soil is reduced and atmospheric conditions cause continuous loss of water by transpiration or evaporation. In drought, plant loses water which in turn resentfully affects the growth and development. Drought has been

\section{${ }^{*}$ Corresponding Author:}

Dr. Bhaskar Sarma,

Assistant Professor,

Department of Botany,

Bodoland University

Kokrajhar, Assam, India.

E-mail: bhaskarsarma252@gmail.com recognized as the primary constraint to rain fed rice production (Chutia et al., 2012; Datta et al., 1975). In Asia $20 \%$ of the total rice cultivation area is subjected to drought and climate change is expected to inflame the situation. It is estimated that more than half of the 40 million hectares of rain fed lowland rice is effected annually (Sarkarung and Pantuwan, 1999). These areas are mainly found in Asia and Southeast Asia, e.g., East India, Bangladesh, Indonesia.

Of the eight North-Eastern states, Assam seems to have suffered the most from the deficit rainfall and high temperatures that prevailed in 2006. Transplanting and sowing of rice were severely hampered. In Assam rainfall is the key to agricultural production. However, irregular rainfall is taking a toll on the state's agricultural produce. After heavy or irregular rainfall and flood Assam may witness extreme drought. It is observed that after a heavy precipitation event, there is less water vapor in the atmosphere, and therefore dry spells tend to longer. In the absence of rain, extra heat exacerbates drying and can contribute to longer and more intense drought periods. So it is feared that the eastern and northeastern region may suffer from extreme drought.

Assam has its climatic and physiographic features favorable for rice cultivation and the crop is grown in a wide range of agro-ecological situations. It is grown from hill slopes of Karbi-Anglong to very deep-water areas of North Lakhimpur and Dhemaji during very wet humid months to drier period of the year. 
Kokrajhar is an administrative district in the state of Assam in North-eastern India. Kokrajhar is the gateway to Assam and other North-eastern state by road as well as railways. Agriculture is the main trade of kokrajhar district and contributes a major part in the district economy. Rice crop covers an area of about $80 \%$ of the Gross Irrigated Area. The Gross Irrigated Area of the district is 1, 77,394ha as against the Net Cropped Area of 1, 08,167 ha with a cropping intensity of $164.20 \%$. In this district double cropping is a regular custom in some major parts of the cultivable land. In 2009, kokrajhar district has been officially declared as drought-hit area. Because there has been a deficit of nearly $30 \%$ rainfall from the beginning of June July received $414.8 \mathrm{~mm}$ of rain in the period as compared to an average rainfall of $588.8 \mathrm{~mm}$. Due to this people have to face an extensive damage and loss to crops.

Drought stress in the soil environment is one of the major constraints affecting rice productivity in the Kokrajhar district, Assam. The present investigation thus is aimed to understand the effect of drought stress on morpho-physiological characteristics and to isolate drought resistant variety among the selected traditional rice cultivars of Kokrajhar district, Assam, India.

\section{Material and Methods}

\section{Plant material and stress conditions}

Seeds of different rice varieties viq. Sali, Bora, Abu, Malsira, and two varieties of Joha vir;, white and black Joha were collected from Patgaon, Kochugaon and Kokrajhar of Kokrajhar district, Assam. Seeds were grown in plastic pots for 23 days. Pots were maintained in a laboratory condition at $28 \pm 1^{\circ} \mathrm{C}, 80 \%$ relative humidity. 23 days grown seedlings were subjected to in vitro drought stress for 21 days. Each experiment was conducted under two conditions irrigated (control) and water deficit. In the controls as well as drought stressed seedlings all parameters were performed on roots and shoots with three replications and five plants were randomly selected from each replica.

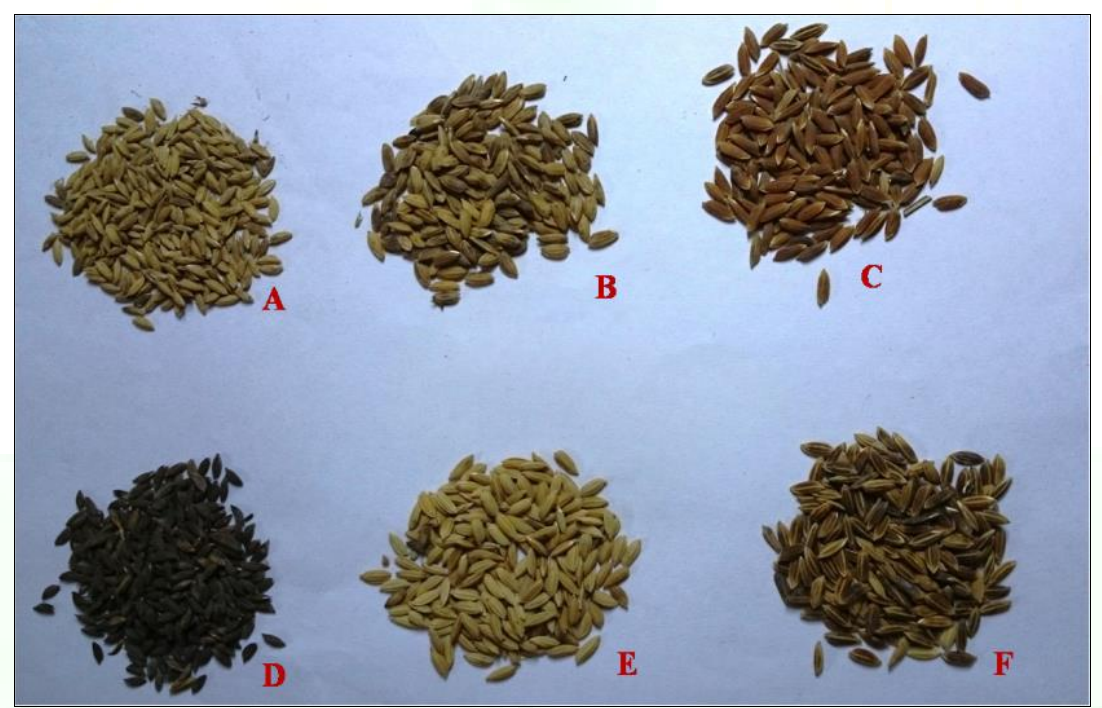

Figure 1: Experimental rice seeds: A. Joha (White), B. Bora, C. Malsira, D. Joha (Black), E. Ahu, F. Sali

\section{Calculation of Germination Index}

The rice seeds were kept at hot air oven for 2 days at $37^{\circ} \mathrm{C} .100$ seeds of each rice varieties were allowed to germinate on a single layer of Whatman No. 1 filter paper in petridishes. Each filter paper was moistened with distilled water. The treatments were replicated for three times. Then above the petridishes moistened filter paper is placed; 100 seeds of rice variety were kept for germination for 7 days at room temperature in dark condition. Numbers of seedlings emerging daily are counted from day of planting the seeds in the petridishes. Thereafter germination indexes (G.I.) were counted by using the following formula:

$$
\text { G.I. }=\mathrm{n} / \mathrm{d}
$$

Where, $n=$ no. of seedlings emerging day ' $d$ ' $\mathrm{d}=$ day after planting.
Root and shoot fresh weights and dry weights

Growth was measured in terms of root and shoot lengths and their fresh and dry weight. Fresh and dry weight of the root and shoot samples were taken after 7, 14 and 21 days of stress condition with the help of weighing balance.

\section{Root architecture}

Root architecture was determined by the mode of spreading of root system, newly emerged roots and mean length of roots after 21 days of stress condition. Length of roots was measured by a meter scale. Photographs of root system were taken by using a digital camera (Cannon power shot $\mathrm{S} \times 400$ IS). 


\section{Leaf traits}

Leaf traits such as leaf length and delay leaf rolling behaviour of selected rice varieties were determined. Mean leaf length was measured by a meter scale after 7, 14 and 21 days accordingly under stress condition. A visual score of the degree of leaf rolling or folding was made on the sample leaf using 1 to 5 scales with 1 being the first evidence of rolling and 5 being a closed cylinder.

\section{Leaf Relative Water Content (LRWC)}

This was determined at vegetative stages of water stress, by cutting top-most fully expanded leaves; leaves were immediately weighed to obtain the fresh weight. The leaves were kept in small sealed plastic bags and kept in ice box. The leaves were then soaked in water for $4 \mathrm{hr}$ and blotted with tissue paper to remove moisture on the leaves. The leaves were weighed to obtain the turgid weight. The turgid leaves were oven-dried at $80^{\circ} \mathrm{c}$ for $24 \mathrm{hr}$. The relative water content was calculated according to the following formula proposed by (Slavick, 1979.)

\section{RWC $(\%)=[(F W-D W) /($ TW-DW $)] \times 100$}

Where, FW is the sample fresh weight, TW is the sample turgid weight and DW is the sample dry weight. Leaf areas were estimated as suggested by O’Neal et al., (2002).

\section{Results}

\section{Germination index (G.I.)}

A positive correlation between germination index (GI) and the whole plant behavior under stress were observed in the present investigation (Table 1). In the present study low germination rate was observed in Malsira.
Table 1: Germination Index of the experimental rice varieties

\begin{tabular}{cc}
\hline Name of rice varieties & Germination Index (G.I) \\
\hline Joha (white) & $35.6 \pm 0.2$ \\
Joha (black) & $30.7 \pm 0.22$ \\
Abu & $30 \pm 0.25$ \\
Bora & $22.78 \pm 0.18$ \\
Sali & $22.3 \pm 0.2$ \\
Malsira & $13.05 \pm 0.21$ \\
\hline
\end{tabular}

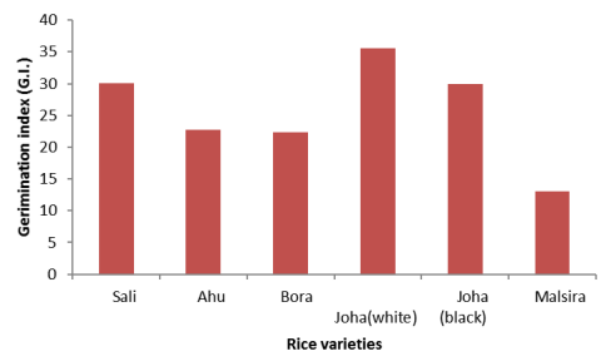

Fig. 2: Graphical representation of germination index of the selected rice cultivars

\section{Root and shoot fresh and dry weights}

The mean performance of the 6 rice genotypes for root and shoot fresh and dry weights conferring drought resistance are presented in Table 2, 3 and 4. Root and shoot fresh and dry weights were recorded at an interval of 7 days for 21 days. Root dry weight varied from 0.06 to 0.024 in the rice Joha (white), 0.016 to 0.022 in Joha (black), 0.014 to 0.019 in $A b u, 0.013$ to 0.018 in Bora, 0.012 to 0.015 in Sali and 0.010 to 0.014 in Malsira and shoot dry weight varied from 0.077 to 0.032 in Joha (white), 0.059 to 0.029 in Joha (black), 0.057 to 0.027 in Abu, 0.055 to 0.025 in Bora, 0.052 to 0.022 in Sali and 0.046 to 0.021 in Malsira. In every observation the Joha (white) variety showed the best performance, where the root dry weights after 7 , 14 and 21 days of stress condition were Sali, Ahu, Bora, Joha (white), Joha (black) and Malsira and shoot dry weights after 7,14 and 21 days were Sali, Abu, Bora, Joha (white), Joba (black) and Malsira. A genotype with high root and shoot weight is expected to be drought tolerant.

Table 2: Mean root and shoot fresh and dry weights of selected rice cultivars after 7 days of stress condition

\begin{tabular}{lllll}
\hline \multirow{2}{*}{ Rice varieties } & \multicolumn{2}{c}{ Root weight (gm) } & \multicolumn{2}{c}{ Shoot weight (gm) } \\
\cline { 2 - 5 } & Fresh (Control) & Dry (Stress) & Fresh (Control) & Dry (Stress) \\
\hline Joha (white) & $0.038 \pm 0.12$ & $0.024 \pm 0.2$ & $0.070 \pm 0.21$ & $0.032 \pm 0.15$ \\
Joha (black) & $0.035 \pm 0.1$ & $0.022 \pm 0.21$ & $0.055 \pm 0.16$ & $0.029 \pm 0.11$ \\
Abu & $0.030 \pm 0.11$ & $0.019 \pm 0.22$ & $0.054 \pm 0.11$ & $0.027 \pm 0.18$ \\
Bora & $0.028 \pm 0.2$ & $0.018 \pm 0.12$ & $0.052 \pm 0.12$ & $0.025 \pm 0.2$ \\
Sali & $0.029 \pm 0.21$ & $0.015 \pm 0.2$ & $0.047 \pm 0.18$ & $0.022 \pm 0.23$ \\
Malsira & $0.017 \pm 0.18$ & $0.014 \pm 0.22$ & $0.038 \pm 0.24$ & $0.021 \pm 0.21$ \\
\hline
\end{tabular}

Table 3: Mean root and shoot fresh and dry weights of selected rice cultivars after 14 days of stress condition

\begin{tabular}{lllll}
\hline \multirow{2}{*}{ Rice varieties } & \multicolumn{2}{c}{ Root weight (gm) } & \multicolumn{2}{c}{ Shoot weight (gm) } \\
\cline { 2 - 5 } & Fresh (Control) & Dry (Stress) & Fresh (Control) & Dry (Stress) \\
\hline Joha (white) & $0.052 \pm 0.11$ & $0.019 \pm 0.2$ & $0.073 \pm 0.21$ & $0.02 \pm 0.13$ \\
Joha (black) & $0.049 \pm 0.1$ & $0.017 \pm 0.21$ & $0.057 \pm 0.12$ & $0.027 \pm 0.11$ \\
Abu & $0.042 \pm 0.11$ & $0.016 \pm 0.2$ & $0.056 \pm 0.11$ & $0.025 \pm 0.12$ \\
Bora & $0.034 \pm 0.2$ & $0.014 \pm 0.12$ & $0.053 \pm 0.12$ & $0.022 \pm 0.2$ \\
Sali & $0.031 \pm 0.22$ & $0.013 \pm 0.2$ & $0.05 \pm 0.16$ & $0.019 \pm 0.22$ \\
Malsira & $0.028 \pm 0.18$ & $0.011 \pm 0.22$ & $0.042 \pm 0.2$ & $0.018 \pm 0.2$ \\
\hline
\end{tabular}


Table 4: Mean root and shoot fresh and dry weights of selected rice cultivars after 21 days of stress condition

\begin{tabular}{lllll}
\hline \multirow{2}{*}{ Rice varieties } & \multicolumn{2}{c}{ Root weight (gm) } & \multicolumn{2}{c}{ Shoot weight (gm) } \\
\cline { 2 - 5 } & Fresh (Control) & Dry (Stress) & Fresh (Control) & Dry (Stress) \\
\hline Joha (white) & $0.066 \pm 0.12$ & $0.016 \pm 0.23$ & $0.077 \pm 0.2$ & $0.18 \pm 0.1$ \\
Joha (black) & $0.051 \pm 0.12$ & $0.01 \pm 0.2$ & $0.059 \pm 0.12$ & $0.016 \pm 0.1$ \\
Ahu & $0.047 \pm 0.21$ & $0.014 \pm 0.2$ & $0.057 \pm 0.14$ & $0.014 \pm 0.12$ \\
Bora & $0.038 \pm 0.2$ & $0.013 \pm 0.14$ & $0.055 \pm 0.12$ & $0.013 \pm 0.2$ \\
Sali & $0.034 \pm 0.22$ & $0.012 \pm 0.21$ & $0.052 \pm 0.16$ & $0.011 \pm 0.2$ \\
Malsira & $0.037 \pm 0.16$ & $0.06 \pm 0.2$ & $0.046 \pm 0.21$ & $0.01 \pm 0.2$ \\
\hline
\end{tabular}

Relative water content (RWC) of leaf

Leaf relative water content of the stressed genotypes, were lower than the unstressed genotypes, at vegetative stage of water stress. The highest reduction of LRWC was exhibited by Malsira with $0.8 \%$ and lowest reduction was recorded $0.05 \%$ by Joha (White) (Table 5).
Table 5. Leaf relative water content of selected rice cultivars

\begin{tabular}{lll}
\hline \multirow{2}{*}{ Rice varieties } & \multicolumn{2}{c}{ RWC } \\
\cline { 2 - 3 } & Control & Stressed \\
\hline Joha (white) & $45 \pm 0.21$ & $80 \pm 0.14$ \\
Joha (black) & $55 \pm 0.2$ & $79 \pm 0.2$ \\
Abu & $35 \pm 0.16$ & $65 \pm 0.2$ \\
Bora & $25 \pm 0.2$ & $30 \pm 0.22$ \\
Sali & $20 \pm 0.21$ & $30 \pm 0.12$ \\
Malsira & $10 \pm 0.1$ & $05 \pm 0.2$ \\
\hline
\end{tabular}

Table 6. Root length of selected rice varieties after 7, 14 and 21 days of drought condition

\begin{tabular}{clll}
\hline \multirow{2}{*}{$\begin{array}{c}\text { Time } \\
\text { duration }\end{array}$} & Rice varieties & \multicolumn{2}{c}{ Root length $(\mathbf{c m})$} \\
\cline { 3 - 4 } & Control & Stress \\
\hline \multirow{7}{*}{7 days (white) } & $15.7 \pm 0.12$ & $8.3 \pm 0.23$ \\
& Joba (black) & $9.03 \pm 0.12$ & $8.1 \pm 0.2$ \\
& Abu & $7.6 \pm 0.21$ & $7.4 \pm 0.2$ \\
& Bora & $8.1 \pm 0.2$ & $7.7 \pm 0.14$ \\
& Sali & $7.1 \pm 0.22$ & $6.6 \pm 0.21$ \\
& Malsira & $6.3 \pm 0.16$ & $5.3 \pm 0.2$ \\
& Joba (white) & $15.9 \pm 0.12$ & $8.8 \pm 0.23$ \\
& Joba (black) & $9.9 \pm 0.12$ & $8.4 \pm 0.2$ \\
& Abu & $8.5 \pm 0.21$ & $7.9 \pm 0.2$ \\
& Bora & $7.8 \pm 0.2$ & $7.6 \pm 0.14$ \\
& Sali & $7.4 \pm 0.22$ & $7.1 \pm 0.21$ \\
& Malsira & $6.5 \pm 0.16$ & $5.7 \pm 0.2$ \\
& Joha (white) & $8.0 \pm 0.12$ & $8.7 \pm 0.23$ \\
& Joha (black) & $7.6 \pm 0.12$ & $7.9 \pm 0.2$ \\
& Abu & $10.2 \pm 0.21$ & $8.8 \pm 0.2$ \\
& Bora & $8.9 \pm 0.2$ & $8.3 \pm 0.14$ \\
& Sali & $16.0 \pm 0.12$ & $9.1 \pm 0.23$ \\
& Malsira & $6.9 \pm 0.16$ & $6.2 \pm 0.2$ \\
\hline
\end{tabular}
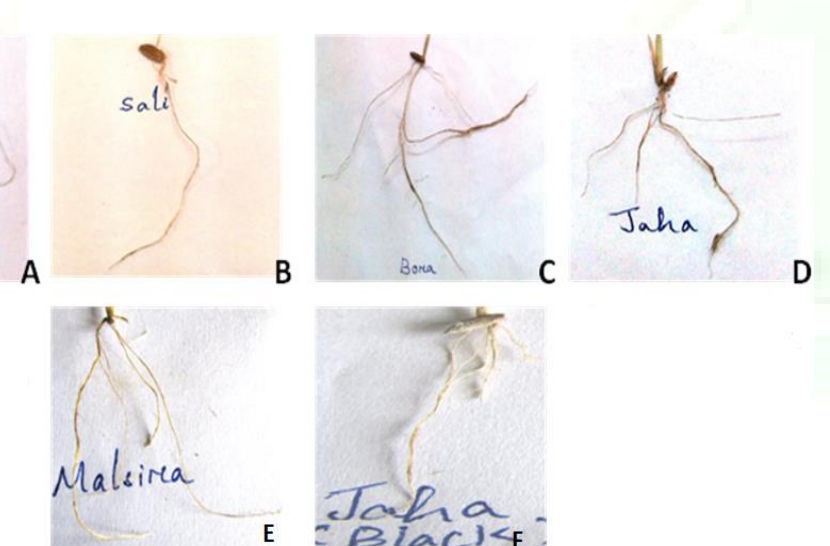

Fig. 3. Root architecture of experimental rice varieties. A. Abu; B. Sali; C. Bora; D. Joha (white); E. Malsira and F. Joha (black)

\section{Root architecture}

In comparison to control, mean root length increased in all the selected rice varieties under stress condition (Table 6$)$. In the present study, 4 genotypes namely Ahu, Bora, Joha (black) and Joha (white) showed high root length $(\mathrm{cm})$ in every observation. Number of primary roots ranged from $6.3-16$.

\section{Leaf traits}

Drought stress induces reduction in plant growth. Drought affects both elongation as well as expansion growth and inhibits cell enlargement more than cell division. All the rice varieties showed gradual decrease in leaf length in response to severity of draught condition. Rice variety Joha 
(white) showed the highest mean leaf length in every observation under stress condition (Table 7).

Leaf rolling, which is a visible sign of drought stress, was observed in all the rice varieties after 7 days of the drought treatment. The controls remained unrolled, but the degree of leaf rolling in all the other cultivars became progressively more pronounced with the drought stress treatment (Fig. 4). After 7 days of the drought treatment, all the cultivars showed a low degree of leaf rolling (Degree 1). When the soil water became more deficient, different degrees of leaf rolling were observed among the cultivars. After 14 days of the treatment Malsira and Bora progressively developed Degree 4 of the leaf rolling symptom, and the other cultivars were at Degree 3. After 21 days of the treatment, Joha (white) was found to develop
Degree 3 of the leaf rolling symptom, Abu, Sali, Joha (black) showed leaf rolling at Degree 4 and Malsira and Bora showed degree 5 of leaf rolling. Leaf death, which is another visible sign of drought stress, developed from the leaf tips and extended to all the plant parts. After 14 days of the treatment, all the cultivars developed Degree 2 of the leaf death symptom in response to drought. Afterwards, different degrees of leaf death were found in the different cultivars. Sali developed the symptom more rapidly than the other cultivars under severe drought stress conditions. Bora showed 60\% leaf death after 21 days of the treatment, and the other cultivars developed leaf death symptoms at percentages greater than $60 \%$. Malsira had the highest percentage of leaf death and Joha (white) was found to be lowest percentage of leaf death.

Table 7: Mean leaf length of selected rice varieties after 7, 14 and 21 days of drought stress condition.

\begin{tabular}{llll}
\hline \multirow{2}{*}{ Time duration } & \multirow{2}{*}{ Rice varieties } & \multicolumn{2}{c}{ Leaf length $(\mathbf{c m})$} \\
\cline { 3 - 4 } & & Control & Stress \\
\hline \multirow{4}{*}{7 days } & Joha (white) & $30.7 \pm 0.12$ & $21.8 \pm 0.23$ \\
& Joha (black) & $24.0 \pm 0.12$ & $21.0 \pm 0.2$ \\
& Ahu & $22.3 \pm 0.21$ & $22.3 \pm 0.2$ \\
& Bora & $16.5 \pm 0.2$ & $24.6 \pm 0.14$ \\
& Sali & $18.5 \pm 0.22$ & $18.5 \pm 0.21$ \\
& Malsira & $12.8 \pm 0.16$ & $12.8 \pm 0.2$ \\
& Joha (white) & $11.6 \pm 0.12$ & $11.6 \pm 0.23$ \\
14 days & Joha (black) & $22.8 \pm 0.12$ & $22.3 \pm 0.2$ \\
& Ahu & $22.0 \pm 0.21$ & $18.5 \pm 0.2$ \\
& Bora & $31.4 \pm 0.2$ & $21.8 \pm 0.14$ \\
& Sali & $22.7 \pm 0.22$ & $23.1 \pm 0.21$ \\
& Malsira & $24.2 \pm 0.16$ & $21.0 \pm 0.2$ \\
& Joha (white) & $31.9 \pm 0.12$ & $21.8 \pm 0.23$ \\
& Joha (black) & $26.0 \pm 0.12$ & $23.1 \pm 0.2$ \\
Ahu & $24.8 \pm 0.21$ & $21.0 \pm 0.2$ \\
& Bora & $22.6 \pm 0.2$ & $20.6 \pm 0.14$ \\
& Sali & $22.9 \pm 0.12$ & $22.3 \pm 0.23$ \\
& Malsira & $13.6 \pm 0.16$ & $12.0 \pm 0.2$ \\
\hline
\end{tabular}

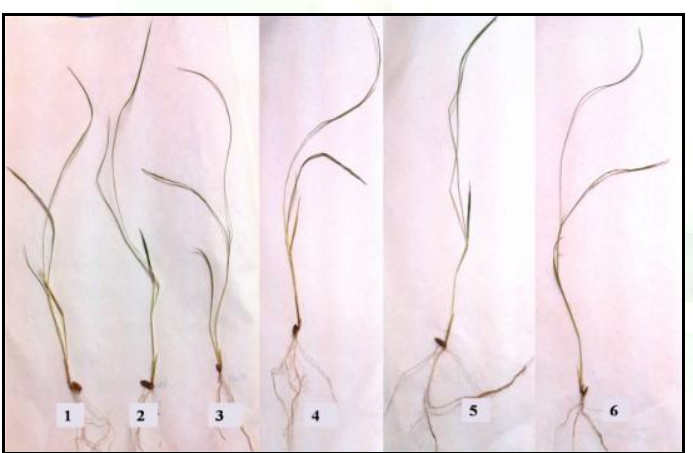

Fig. 4. Leaf rolling behavior of the rice varieties 1 . Sali; 2. Abu; 3. Bora; 4. Joha (white); 5. Joha (black) and 6. Malsira

\section{Discussion}

Germination and seedling development under laboratory conditions have been accepted as suitable growth stages for testing the response to abiotic stresses (Sharif-zadeh and Mohsen 2008).

In the present study low germination rate was observed in Malsira. On the other hand high germination rate was observed in Joha (white).
Thus the determination of germination index (GI) can be used just as an easy and reliable parameter for measuring drought sustenance among the traditional rice cultivars.

Drought stress directly affects the growth of rice plants by reducing plant height and the number of tillers per plant because plants are unable to absorb soil water when soil water becomes inadequate, resulting in the essential elements being less available to the plants. The plant cells become less turgid, leading to a reduction in cell division and expansion. Therefore, the growth of the stems is retarded (Hsiao et al, 1984). In the present study gradual decrease in plant height was observed in all the rice cultivars as the drought condition becomes more severe. However, the rice variety Joha (white) showed better response regarding the maintenance of plant height reduction during drought condition than the other rice cultivars. Plants also respond to water deficit by developing the leaf rolling symptom. All the cultivars showed higher degrees of leaf rolling when the levels of water deficit were elevated. Based on the results from this study, Joha 
(white) showed a lower degree of leaf rolling than the other cultivars. These findings were in agreement with the results of Dingkuhn et al., (1991), who reported that leaf rolling is one of the mechanisms found in plants to escape drought. This mechanism can be explained by the plants adjusting their leaf water potential to allow them to absorb soil water better than other plants with low capabilities to adjust their leaf water potential under drought stress. As a result, leaf rolling is uncommon in these better-adjusting plants, so their photosynthesis was not prohibited. Leaf death is another visible sign of drought stress that plants initially develop from the leaf tips. According to the findings obtained in this study, Joha (white) showed the lowest degree of leaf death. Sigari et al., (1997) reported that the degree of leaf rolling is related to leaf death. Plants with a good capacity for leaf water potential adjustment can keep their leaves expanded such that the symptoms of leaf rolling and death are not developed, suggesting that the plants can rapidly recover from drought. Under severe drought stress, a reduction was found in the LRWC (Leaf Relative Water Content) in all the rice cultivars. Based on the present study, Joha (white) was the only cultivar that was able to maintain its LRWC. Munns (2002) reported that a reduction in leaf water content occurs when soil water becomes deficient, resulting in the plants being less able to absorb water and leading to a decrease in turgidity and leaf water potential. The present study indicated that various cultivars can resist drought differently. Nguyen et al., (1997) stated that drought-tolerant cultivars can maintain the water status in their leaves, which demonstrates their ability to cope with drought stress.

Type of root system is also a good selection criterion for selecting the drought tolerance line or varieties. Deep root system has been identified as the targeted for drought tolerance improvement (Boyer, 1996). Production of root system under drought is very important and had good correlation with yield under moisture stress (Darofeev and Tyselano, 1982).

Drought affected plants generally exhibit small root system configuration and in many causes the reduction in size of root system is directly proportional to the magnitude of water storage. According to Slayter, 1973 two types of effects of water deficit on root development can be exposed, first is reduction in rate of meristematic activity and root elongation directly associated with the level of internal water deficit and second effect of suberization on the water and nutrients uptake proportional of the root system as whole. In the present study, three genotypes viz. Joha (white), Joha (black) and Bora showed high root length (cm). Number of primary roots ranged from 6.316 (Fig. 3).
High dry weight under water stress conditions is a desirable characteristic for survivability of the plant under water stress condition. A common adverse effect of water stress on crop plant is reduction in fresh and dry biomass production (Farooq et al., 2009). In every study Joha (white) showed best response regarding the fresh and dry biomass production.

A plant having the characteristics of delay leaf rolling under water stress and faster recovery rate after removing the water stress in rice (Singh and Mackill, 1991) was considered as good trait because flag leaf in rice crops plays the important role in grain filling and development (Evans et al., 1975). In the present study Joha (white) and Joha (black) showed faster recovery rate than the other rice cultivars after removing the drought stress.

In conclusion the studied rice cultivars displayed different abilities to resist drought. Based on the present study, the rice cultivars could be classified into 3 categories based on their responses to drought. Joha (white) was a highly drought-tolerant cultivar. Joha (black), Abu, Sali and Bora were considered to be moderately drought-tolerant cultivars, and Malsira was considered to be sensitive to drought.

\section{References}

1. Achari, Basudeb, Chakrabarty, Sarmistha, Pakrashi, Satyesh C., An N-glycoside and steroids from Aristolochia indica. Phytochem. 20, (1981): 1444-1445.

2. Boyer, John S., Advances in drought tolerence in plants. Adv. Agron. 56, (1996): 187-218.

3. Chutia, Jnanadabhiram, Borah, Sailendra P., Tanti, Bhaben, Effect of drought stress on protein and proline metabolism in seven traditional rice (Oryza sativa Linn.) genotypes of Assam, India. J. Res. Biol. 2.3, (2012): 206-214.

4. Darofeev, V.F., Tyselano, A.M., Number of seminal roots in spring wheat in the course of selecting pair for hybridization. Vestnik Selokokhozysist. 8, (1982): 50-56.

5. Datta, Surajit K. De., Chang, T.T., Yoshida, S., Drought tolerance in upland rice. Major Res. Upland Rice. IIRI, Los Bonos, Languna, Philippines, (1975): pp. 101-105.

6. Dingkuhn, M., Cruz, R.T., O’Toole, L.C., Turner, N.C., Doerffling, K., Responses of seven diverse rice cultivars to water deficits. III. Accumulation of abscisic acid and proline in relation to leaf waterpotential and osmotic adjustment. Field Crops Res. 27, (1991): 103-117.

7. Evans, L.T., Wardlaw, I.F., Fisher, R.A., In: Crop Physiologysome case stories. Evans L.T. (ed.), Cambridge University Press, London, (1975): pp. 101-149. 
8. Farooq, M., Wahid, A., Kobayashi, N., Fujita, D., Basra, S.M.A., Plant drought stress: effects, mechanisms and management. Agron. Sustain. Dev. 29, (2009): 185-212.

9. Foley, J.A., Ramankutty, N., Braumann, K.A., Cassidy, E.S., Gerber, J.S., Johnston, M., Mueller, N.D., O'Connell, C., Ray, D.K., West, P.C., Balzer, C., Bennett, E.M., Carpenter, S.R., Hill, J., Monfreda, C., Polasky, S., Rockström, J., Sheehan, J., Siebert, S., Tilman, D., Zaks, D.P.M., Solutions for a cultivated planet. Nature. 478, (2011): 337342.

10. Hanson, A.D., Peacock, W.J., Evans, L.T., Arntzen, C.J., Khus, G.S., Development of drought resistant cultivars using physiomorphological traits in rice. (eds. Fukai S. and Cooper M.). Field Crop Res. 40, (1995): 67-86.

11. Hsiao, T.C., O’Toole, J.C., Yambao, E.B., Turner, N.C., Influence of osmotic adjustment on leaf rolling and tissue death in rice (Oryza sativa L.). Plant Physiol. 75, (1984): 338-341. doi:10.1104/pp.75.2.338.

12. Khush, G.S., What it will take to feed 5.0 billion rice consumers in 2030. Plant Mol. Biol. 59, (2005): $1-6$.

13. Munns, R., Comparative physiology of salt and water stress. Plant Cell Environ. 25, (2002): 239-250.

14. Nguyen, H.T., Babu, R.C., Blum, A., Breeding for drought resistance in rice: Physiological and molecular genetics considerations. Crop Sci. 37, (1997): 1426-1434.

15. Sarkarung, S., Pantuwan, G., Improving rice for drought prone rain fed lowland environment. In: ito, O., O' Toole, J.C., Hardy, B. (Eds.), Genetic Improvement of Rice for Water limited Environments. International Rice Research Institute, Los Banos, Philippines, (1999): pp. 57-70.
16. Sharif-zadeh, F., Mohsen, J., Influence of priming techniques on seed germination behavior of maize inbreed lines (Zea mays L.). J. Agri and Bio Sci. 3, (2008): 22-25.

17. Singh, H., Mackil, 1.K.T., Sensitivity of rice to water deficit at different growth stages. Phil. Crop Sci. 16(suppl.no.10), (1991): S11.

18. Sigari, A., Wadel, L.J., Yamauch, A., "Response of Roots Traits of Rainfed Lowland Rice to Drought and Rewatering," In: J. Abe and S. Morita, Eds., Root System Management that Leads to Maximize Rice Yields, JSRR, Tokyo. (1997): pp. 132-140.

19. Slavick, B., Methods of studying plant water relation. Springer-Verlang. New York. (1979): pp. 1114-1120.

20. Slayter, R.O., The effect of internal water status on plant growth, development and yield. In: Plant Response to Climatic Factors. Slayter, R.O. (eds.). Proc. Uppsala Symp. UNESCO, Paris. (1973): pp. 177-191.

21. O'Neal, M., Douglas, A.L., Rufus, I., An inexpensive, Accurate Method for Measuring Leaf Area and Defoliation through Digital Image Analysis. J. Entomol. 95, (2002): 1190-1194.

22. Wang, J.H., Geng, L.H., Zhang, C.M., Research on the weak signal detecting technique for crop water stress based on wavelet denoising. Adv Mat Res. 424/425, (2012): 966-970.

\section{Cite this article as:}

Bhaskar Sarmaa, Neeva Rani Basumatarya, Shamsun Naharb, Bhaben Tanti. Effect of drought stress on morphophysiological traits in some traditional rice cultivars of Kokrajhar district, Assam, India. Annals of Plant Sciences 5.7 (2016): 1402-1408.

DOI: http://dx.doi.org/10.21746/aps.2016.08.003
Source of support: Nil

Conflict of interest: None Declared 